\title{
Perturbation of a Human Gut Ecosystem by Silver Chloride Colloids
}

\section{Pranab Das $^{1 *}$, Elaine O Petrof ${ }^{2}$ and Virginia K Walker ${ }^{1,3}$}

${ }^{1}$ Department of Biology, Queen's University, Kingston, ON K7L 3N6, Canada

${ }^{2}$ Department of Medicine, Kingston General Hospital, Queen's University, Kingston, ON K7L 2V7, Canada

${ }^{3}$ Department of Biomedical and Molecular Sciences, and School of Environmental Studies, Queen's University, Kingston, ON K7L 3N6, Canada

\begin{abstract}
The bactericidal and fungicidal properties of silver $(\mathrm{Ag})$ and $\mathrm{Ag}$ salt colloids make them popular choices for a variety of applications including water purification, bio-medical therapies for burns, epilepsy, mental illness, gastroenteritis, syphilis and gonorrhea, amongst other diseases. In addition, individuals deliberately drink colloidal $\mathrm{Ag}$ and $\mathrm{Ag}$ salts in the belief that this self- therapy will be beneficial. Despite this widespread usage, very little is known about the impact of this metal on human gut consortia. Here we investigated the impact of Ag chloride colloids, at several concentrations, on a defined anaerobic and facultative anaerobic gut bacterial community developed from the collected stool of a healthy donor. Defined microbial ecosystem therapeutic- 1 (MET-1) consortia were exposed to different concentrations of colloidal $\mathrm{Ag}(25-200 \mathrm{mg} / \mathrm{L})$ for $48 \mathrm{hrs}$ and compared to unamended cultures. Carbon dioxide and nitrogen gases recovered from the headspace of anaerobic cultures were analyzed by an Agilent Technologies 7890B Gas Chromatograph. Fatty acid methyl ester profiles were extracted following the MIDI Sherlock Microbial Identification System protocol and detected by gas chromatography. Colloidal $\mathrm{AgCl}$ toxicity was also monitored by a suite of DNA analyses including polymerase chain reaction (PCR), denaturing gradient gel electrophoresis (DGGE) and 16S ribosomal RNA gene fragment 454-pyrosequencing. Colloidal $\mathrm{AgCl}$ had an overall deleterious impact on MET-1 bacterial abundance and their metabolic activities as evidenced by the $20-78 \%$ reduction in $\mathrm{CO}_{2}$ respiration and significant $(\mathrm{p}<0.01)$ changes in fatty acid profiles, including a greater reduction (15 - 100\%) in most Gram negative signatures compared to controls. Multidimensional scaling and cluster analysis produced from PCR-DGGE profile-based DNA analysis, as well as gene sequencing also demonstrated the negative impact of colloidal Ag on MET-1, resulting in a shift in the community structure, including the apparent elimination of some beneficial species. Together, this research suggests that deliberate or inadvertent colloidal Ag ingestion could have a potential negative impact on our overall digestive health.
\end{abstract}

Keywords: Colloidal silver; Silver salt; Silver chloride; Microbial ecosystem therapeutic; Toxicity; Human intestinal microbiota

\section{Abbreviations}

AgCl: Silver chloride; MET-1: Microbial ecosystem therapeutic-1; $\mathrm{CO}_{2}$ : Carbon dioxide; $\mathrm{N}_{2}$ : Nitrogen; $\mathrm{H}_{2}$ : Hydrogen; GC: Gas chromatograph; FAME: Fatty acid methyl ester; PCR: Polymerase chain reaction; DGGE: Denaturing gradient gel electrophoresis; AgNPs: Silver nanoparticles; $\mathrm{AgNO}_{3}$ : Silver nitrate; $\mathrm{NaCl}$ : Sodium chloride; $\mathrm{Ag}^{+}$: Silver ion; $\mathrm{Cl}^{-}$: Chloride ion; ICP-MS: Inductively coupled plasma-mass spectrometry; NCBI: National center for biotechnology information; ANOVA: Analysis of variance; UPGMA: Unweighted pair group method with arithmetic mean; MDS: Multidimensional scaling

\section{Introduction}

Silver (Ag) is a xenobiotic element; it has not been identified as an essential trace element for mammals, nor is it known to fulfill any significant physiological role in tissues even after interaction with essential elements [1,2]. Nonetheless, because of their bactericidal and fungicidal properties, $\mathrm{Ag}$ or $\mathrm{Ag}$ salt colloids have been used in many applications including cosmetics and medical treatments such as wound infections, epilepsy, mental illness, venereal diseases, gastroenteritis, syphilis, gonorrhea amongst others [3-7]. Ag has also been used in water purification systems in many developing countries and as well as to safeguard hospital hot water systems as a protection against Legionella infections [8,9]. Independent of such use, there is a wide range of ingested $\mathrm{Ag}(1-27 \mu \mathrm{g} / \mathrm{day}$; [10-12]), but typically, low tissue levels $(\sim 0.05 \mu \mathrm{g} / \mathrm{g})$ are reported [13]. These levels can be much higher in people exposed to Ag either inadvertently by occupation, or intentionally. Some individuals deliberately drink colloidal Ag and Ag salts in the belief that this self-treatment will be beneficial, and Ag species are then deposited into their tissues [14,15]. Indeed, a bluegrey discoloration of the human skin, argyria or 'blue man disease' is a well-known hallmark of oral colloidal Ag self-therapy [16,17]. The consequence of such exposure is not clear. Although, elemental silver in the colloid is inactive in presence of human tissues, there is the possibility of ionization in presence of body fluids $[2,4]$. The resulting biologically active $\mathrm{Ag}^{+}$has a strong affinity for sulfhydryl groups, cell membranes and other anionic protein ligands, and finally poses a potential risk to the denaturation and inactivation of proteins and enzymes [2-4]. Disorders of the cardiovascular and reproductive systems have been detected in rats after exposure to $\mathrm{Ag}$ chloride $(\mathrm{AgCl})$ in drinking water $[18,19]$, and a neurological disorder has been observed after human oral ingestion of colloidal Ag [20]. Strikingly, we know very little about the impact of colloidal Ag on the human gut ecosystem.

The human gut microbiota is known to be a dense and very diverse ecosystem with more than $10^{14}$ gut bacteria playing an important role in host health $[21,22]$. Due to the intimate relationship between the gut

*Corresponding author: Pranab Das, Department of Biology, Queen's University, Kingston, ON K7L 3N6, Canada, Tel: +1 613- 533-6000 (ext-77360); Fax: 613-5336617; E-mail:pd50@queensu.ca

Received May 11, 2015; Accepted May 23, 2015; Published May 28, 2015

Citation: Das P, Petrof EO, Walker VK (2015) Perturbation of a Human Gut Ecosystem by Silver Chloride Colloids. J Environ Anal Toxicol 5: 294. doi:10.4172/2161-0525.1000294

Copyright: (C) 2015 Das P, et al. This is an open-access article distributed under the terms of the Creative Commons Attribution License, which permits unrestricted use, distribution, and reproduction in any medium, provided the original author and source are credited. 
microbiota and the host, changes in intestinal microbial communities can disrupt physiological functions with the potential for pathology $[23,24]$. A proxy for in vivo human studies can be achieved by using a synthetic stool mixture of dozens of distinct beneficial isolates, which not only mimics a healthy gut ecosystem but can be reproducibly and reliably cultured [25]. Using such a mixture, designated as microbial ecosystem therapeutic-1 (MET-1), we have recently observed that the community could be impacted by Ag, nanoparticle (AgNP) treatments [26]. As indicated, the use of Ag both in water purification systems and because of alternative health practices, appears to be increasing $[5,8,9,16,27,28]$. Therefore, we hypothesized that ingestion of Ag salt colloids, as aliquots of $\mathrm{AgCl}$, could also perturb the human microbial community. Here we have evaluated the responses of MET-1 to $\mathrm{AgCl}$ colloids in three distinct toxicity assays including respiration, fatty acid methylesters (FAME), and DNA sequence analysis using both denaturing gradient gel electrophoresis (DGGE) fingerprinting and 454-pyrosequencing.

\section{Materials and Methods}

\section{Silver chloride colloid preparation}

Aliquot of $\mathrm{AgCl}$ colloids were prepared from crystalline silver nitrate $\left(\mathrm{AgNO}_{3}\right.$; Fisher Scientific) and sodium chloride (NaCl; Fisher Scientific) as previously described [26]. Briefly, solutions of $\mathrm{AgNO}_{3}$ $(140 \mathrm{mM})$ and $\mathrm{NaCl}(280 \mathrm{mM})$ were made individually by dissolving in sterile MilliQ-water. The solutions were mixed (1:1) and simultaneously diluted 10 -fold with sterile MilliQ-water by vortexing $(\sim 1000 \mathrm{rpm})$ to reach an $\mathrm{AgCl}$ concentration of $\sim 1000 \mathrm{mg} / \mathrm{L}$. The two-fold higher $\mathrm{NaCl}$ concentration ensured that no residual silver ion $\left(\mathrm{Ag}^{+}\right)$was present in the $\mathrm{AgCl}$ colloidal suspension. The final concentration of the $\mathrm{AgCl}$ working solution was determined by inductively coupled plasma-mass spectrometry (ICP-MS; XSeries II; Thermo Scientific, Germany), as described [29].

\section{The human gut ecosystem culture and treatment groups}

The human gut ecosystem used, microbial ecosystem therapeutic-1 (MET-1), is a synthetic stool mixture of 33 different bacterial species, formulated by extensive culture [25]. Briefly, each bacterial species was individually cultured on fastidious anaerobe agar under anaerobic conditions $\left(90 \% \mathrm{~N}_{2}, 5 \% \mathrm{CO}_{2}, 5 \% \mathrm{H}_{2}\right)$, and then cultured together [25]. The MET-1 suspension was placed in an air-tight double-sealed container and a defined sterile growth medium [30] was used for the batch culture experiments [26] used in this study. The MET- 1 bacterial suspension was added to defined sterile growth medium (1:10 dilution) in sterile glass serum bottles ( $50 \mathrm{~mL}$; Sigma Aldrich) to a final volume of $5 \mathrm{~mL}$ for each $\mathrm{Ag}$ treatment including control with no Ag. The suspensions were then placed in a Ruskinn anaerobic chamber (The Baker Co., Sanford, USA) containing an appropriate atmosphere (90\% $\mathrm{N}_{2}, 5 \% \mathrm{CO}_{2}, 5 \% \mathrm{H}_{2}$ ) at $37^{\circ} \mathrm{C}$.

Triplicate cultures of each of four treatment groups consisted of 25, 100 and $200 \mathrm{mg} / \mathrm{L}$ of $\mathrm{AgCl}$ colloids and triplicate control cultures not amended with $\mathrm{AgCl}$. After AgCl colloid additions, the serum bottles (assuming a pressure of one atmosphere of the anaerobic gas mixture in each) were clinched with $20 \mathrm{~mm}$ sterilized rubber stoppers and secured using Wheaton ${ }^{\mathrm{TM}}$ aluminium seals (both Fisher Scientific), and then incubated in the dark room for $48 \mathrm{~h}$ at $37^{\circ} \mathrm{C}$ in a sealed vessel containing a Gaspak ${ }^{\mathrm{TM}} \mathrm{EZ}$ anaerobic gas pouch (Fisher Scientific) while being shaken $(\sim 10 \mathrm{rpm})$ on a Bigbill Thermolyne shaker (Dubuque, USA). As indicated, a range of concentrations was used, since, to our knowledge, there has been no study on the toxic effects of $\mathrm{AgCl}$ colloids to human gut ecosystems. For the upper level, it is known that argyria is associated with a body burden of $\sim 65 \mathrm{mg} / \mathrm{L}$ [31], and an individual who developed complications from self- administered 'therapeutic' Ag ions was estimated to have imbibed the equivalent of $150 \mathrm{mg} / \mathrm{L}$ in all fluids in a single day [32], which would result in up to $600 \mathrm{mg} / \mathrm{L}$ in the digestive tract, discounting any cellular absorption. Since these doses would represent extreme conditions, it seemed reasonable to use them as a guide for the highest concentration tested.

\section{MET-1 gas generation analyses}

MET-1 gas generation was sampled and analyzed as described [26]. Briefly, the gas was sampled in situ after 24 and $48 \mathrm{~h}$ incubation and immediately injected into an Agilent Technologies 7890B Gas Chromatograph (GC; Palo Alto, California, USA), equipped with a stainless steel column and packed with Agilent J\&W PoraBOND Q (Palo Alto, California, USA). For gas production analyses, two major peak areas of $\mathrm{CO}_{2}$ and $\mathrm{N}_{2}$ were determined using Agilent Technologies Chem Station Integration Software (Palo Alto, California, USA).

\section{Fatty acid analyses}

Phospholipid fatty acids were extracted from triplicate pellets, prepared from a subsample $(1 \mathrm{~mL})$ of each bottle by centrifugation at $2000 \mathrm{xg}$ for $10 \mathrm{~min}$, and subsequently using the MIDI Sherlock Microbial Identification System (Microbial ID Inc., Newark, DE, USA) as described [33] (Keystone Labs; Edmonton, Canada). Briefly, each pellet was saponified $\left(30 \mathrm{~min}\right.$ at $100{ }^{\circ} \mathrm{C}$ using $1 \mathrm{~mL}$ of $\mathrm{NaOH}$ in aqueous methanol, $15 \% \mathrm{w} / \mathrm{v})$, methylated $\left(10 \mathrm{~min}\right.$ at $80^{\circ} \mathrm{C}$ with $2 \mathrm{~mL}$ $\mathrm{HCl}$ in aqueous methanol, $54 \% \mathrm{w} / \mathrm{v}$ ), extracted (10 min using $1.25 \mathrm{~mL}$ of hexane/methyl-tert- butyl ether, $50 \% \mathrm{v} / \mathrm{v}$ ), washed ( 5 min using 3 $\mathrm{mL}$ of $0.3 \mathrm{M} \mathrm{NaOH}$ containing a few drops of saturated $\mathrm{NaCl}$ ), and the organic phase analyzed with a GC equipped with flame ionization detector (Agilent). The chromatographic peak areas were converted to mol\% of total fatty acids for each sample. All abundant fatty acids $(>0.15 \% \mathrm{~mol} \%)$ were then further analyzed and sub-grouped into Gram positive, Gram negative and saturated categories, as stated [34].

\section{DNA extraction and PCR-DGGE}

Each culture was sampled $(200 \mu \mathrm{L})$ at the end of the $48 \mathrm{~h}$ incubation period and genomic DNA extracted using a QIAamp DNA stool mini kit (Qiagen Sciences, LLC, MD, USA) following the manufacturer's protocol. The extracted DNA was stored $\left(-20^{\circ} \mathrm{C}\right)$ until used as a template for polymerase chain reaction (PCR). Genomic DNA was PCR amplified in triplicated in a Veriti 96 Well Thermal Cycler (Applied Biosystems, Burlington, Canada) with the primer pairs: $341 \mathrm{~F}$ (5'-CCTACGGGAGGCAGCAG) with an additional 40-nucleotide GC-rich sequence on the 5 'end (GC clamp) and 518R (5'- ATTACCGCGGCTGCTGG; [35]). The PCR conditions included denaturation for $5 \mathrm{~min}$ at $94{ }^{\circ} \mathrm{C}$, followed by 30 amplification cycles $\left(1 \mathrm{~min}\right.$ at $94{ }^{\circ} \mathrm{C}, 1 \mathrm{~min}$ at $64{ }^{\circ} \mathrm{C}, 3 \mathrm{~min}$ at $72{ }^{\circ} \mathrm{C}$ ) with a final extension for $7 \mathrm{~min}$ at $72{ }^{\circ} \mathrm{C}$. After size confirmation by electrophoresis on $1 \%$ (wt/vol) agarose gels and visualization with an ultraviolet (uv) light transilluminator, the PCR-amplified gene fragments were then analyzed by DGGE as described [26]. Subsequently, the DGGE-generated images were analyzed by Syngene Genetools software (version 4.03.03, Synoptics Ltd.).

\section{DNA sequence analyses}

Bacterial tag-encoded pyrosequencing of MET-1 community (in triplicate treatment groups) was performed on a Genome Sequencer Roche 454 FLX Titanium platform (Roche, Nutley, NJ) by the 
Research and Testing Laboratory (MR DNA; Shallowater, TX, USA) following standard protocols. Details of the sequence data processing and analysis have been described [26]. Concisely, after amplification of the $500 \mathrm{bp} \mathrm{V1}$ to V3 region with 16S rRNA primers (Gray 28f: 5'-TTTGATCNTGGCTCAG and Gray519r: 5'-GTNTTACNGCGGCK GCTG) [36], sequencing reads were subjected to a distributed MegaBLAST.NET algorithm and outputs evaluated by the .NET and $\mathrm{C \#}$ analysis pipeline. Bacterial identity was based on the percentage of the total length of each sequence aligned with $16 \mathrm{~S}$ sequences of the National Center for Biotechnology Information (NCBI) database library RDP ver 9 and also in comparison with the known MET-1 sequences. Finally, the 454 pyrosequencing distributions in each treatment group were then normalized using the corresponding total mol\% fatty acids profiles [26].

\section{Statistical analyses}

The impact of $\mathrm{AgCl}$ colloids on MET-1 community gas production, FAME analysis and DNA sequence were assessed with two-way analysis of variance (ANOVA) using SPSS (SPSS Inc., Illinois). The significant differences between any two pairs of means were evaluated by Tukey's HSD post-hoc test. Dendrogram plots of DGGE bands profiles were based on the banding patterns with intensity assessed using the Pearson correlation coefficient and UPGMA (Unweighted Pair Group Method with Arithmetic Mean) methods. Multidimensional scaling (MDS) of human gut bacterial community composition from the phylogenetic sequences of equal length was used to compare multivariate responses to the concentrations of $\mathrm{AgCl}$ colloids including control treatments (no Ag) using SAS Ver 9.4 (SAS Institute, Inc.).

\section{Results}

\section{Effects on MET-1 gas production}

Total gas volumes ( $\mathrm{CO}_{2}, \mathrm{~N}_{2}$ and unidentified gas) in the head space of the MET-1cultures were significantly reduced by $\sim 20-36 \%(p<$ $0.05)$ in the $25-200 \mathrm{mg} / \mathrm{L} \mathrm{AgCl}$ treatment groups compared to control treatments. This reduction was correlated with a lower production of $\mathrm{CO} 2$, which was significantly reduced $(p<0.05)$ by $20-78 \%$ at $\mathrm{AgCl}$ concentrations in a dose dependent manner (Figure 1). Consequently, the proportion of MET-1 generated N2 gas was raised at increasing $\mathrm{AgCl}$ concentrations and significantly different $(p<0.05)$ at 100 and 200 $\mathrm{mg} / \mathrm{L} \mathrm{AgCl} \mathrm{treatment} \mathrm{groups} \mathrm{compared} \mathrm{to} \mathrm{the} \mathrm{control.}$

\section{Effects on MET-1 fatty acid profiles}

Phospholipid fatty acid signatures were significantly influenced $(p<0.05)$ after colloid Ag treatment (Figure 2). Of 31 different fatty acid chromatographic peaks, the dominant $23(>0.15 \mathrm{~mol} \%)$ were selected for comparative analysis. Most Gram negative signatures were reduced by $15-100 \%$ in the $\mathrm{AgCl}$ treatment groups, whereas a few Gram positive and most saturated signature fatty acids (e.g. 18:1 $\omega 9 \mathrm{C}$, 16:00) were increased by $13-45 \%$. However, saturated capric (10:0) and stearic (18:0) fatty acids were also reduced by $65-90 \%$ and $30-$ $35 \%$, respectively, in $\mathrm{AgCl}$ treatments compared to control. Regardless of any increase or decrease, however, the total fatty acids profiles were positively correlated $(r=0.682 ; p \leq 0.01)$ with the reduction in the total gas volume after $48 \mathrm{~h}$ exposure. Together these independent assays indicated a colloidal AgCl-mediated toxicity for the MET-1 community.

\section{Effects on DNA analyses}

The UPGMA based hierarchical cluster analysis of DGGE banding profiles showed that after treatment with colloidal AgCl, the MET-1

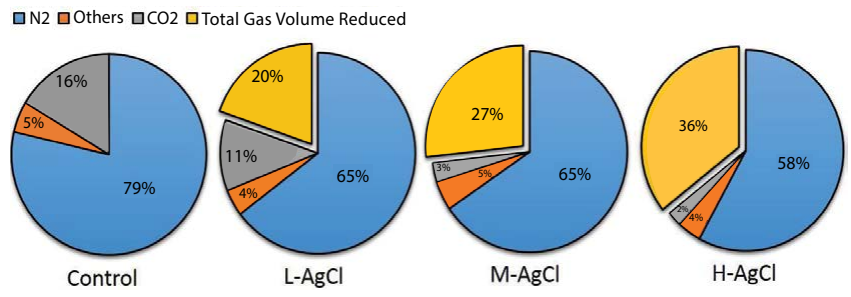

Figure 1: Carbon dioxide $\left(\mathrm{CO}_{2}\right)$ and nitrogen $\left(\mathrm{N}_{2}\right)$ gas recovered from the total gas generated by the MET-1 bacterial communities after $48 \mathrm{~h}$ exposure to $\mathrm{AgCl}$ and control (no $\mathrm{Ag}$ ), where $\mathrm{L}-, \mathrm{M}$ - and $\mathrm{H}$ - prefixes on $\mathrm{AgCl}$ represent 25,100 and $200 \mathrm{mg} / \mathrm{L}$ concentrations, respectively. The percentage of the total gas volume reduced after exposure to $\mathrm{AgCl}$ colloids, compared to the control, is shown in the separated pie slice of the $\mathrm{AgCl}$ treatment groups.

communities grouped separately from the control group, differing by $17 \%-42 \%$ depending on the concentration (Figure 3, Left Panel). PCRDGGE analysis showed differences in banding patterns and intensities in the colloidal $\mathrm{AgCl}$ and control treatment groups with a few bands completely disappearing at the higher treatment concentrations (not shown).

DNA sequencing from each of the triplicate treatment groups was consistent with the PCR-DGGE results in that there was a significant reduction $(p<0.01)$ in diversity, which ranged from $14-36 \%$ at increasing colloidal $\mathrm{AgCl}$ concentrations compared to the controls (Figure 3, Panels A-D). Only relatively abundant sequences (reads $\geq 1 \%$ ) were used in this analysis, however, it must be noted that a significant difference $(p<0.05)$ was also observed between exposure groups when the minor contributors of MET-1 community (defined as 'Others' group) were considered. For example, no sequences corresponding to the low abundant species Collinsella aerofaciens $(\sim 0.16 \%)$, Dorea longicatena $(\sim 0.2 \%)$, Eubacterium desmolans $(\sim 0.13 \%)$ and Ruminococcus obeum $(\sim 0.1 \%)$ were recovered after colloidal $\mathrm{AgCl}$ exposure. In addition, even at the lowest colloidal AgCl exposure, there were shifts in the evenness of the consortium. For example, the strict Gram negative anaerobe, Bacteroides ovatus $(\sim 35 \%)$ was significantly $(p<0.001)$ reduced by $\sim 84 \%$ after $25 \mathrm{mg} / \mathrm{L}$ colloidal AgCl exposure compared to the control, but appeared to be less impacted at higher $\mathrm{AgCl}$ treatments. Ruminococcus torques $(\sim 2 \%)$ showed a similar reduction $(80 \%)$ at the lowest concentration. Depending on the species a different effect was also observed; the proportion of Gram negative Raoultella sp. $(\sim 23 \%)$ and Escherichia coli $(6 \%)$ were significantly increased $(p<0.01)$ in the lowest $\mathrm{AgCl}$ treatment groups, but decreased by $64 \%$ and $65 \%$, respectively, at the highest $\mathrm{AgCl}$ exposures relative to the controls. The balance of the anaerobes such as Roseburia faecalis ( $\sim 5.5 \%)$, Eubacterium rectale $(\sim 5 \%)$, Roseburia intestinalis (4\%) and Acidaminococcus intestinalis $(\sim 2.3 \%)$ were also significantly decreased $(p<0.01)$ by $91-95 \%, 82-$ 96\%, 76 - 92\% and 84 - 92\%, respectively, after $\mathrm{AgCl}$ treatments (Figure 3). MDS analysis confirmed these observations and showed that the phylogenetic compositions in the treatment groups were clearly distinct from the controls (Figure 3, Panel E). Samples from the lowest $\mathrm{AgCl}$ exposure group were shifted away from those of the two higher concentrations as well as the controls, suggesting some variable toxicity at different $\mathrm{AgCl}$ concentrations.

\section{Discussion}

Research with a variety of animal models, as well as case studies in humans, have shown that health concerns associated with colloidal Ag are low, notwithstanding the dramatic change in the 


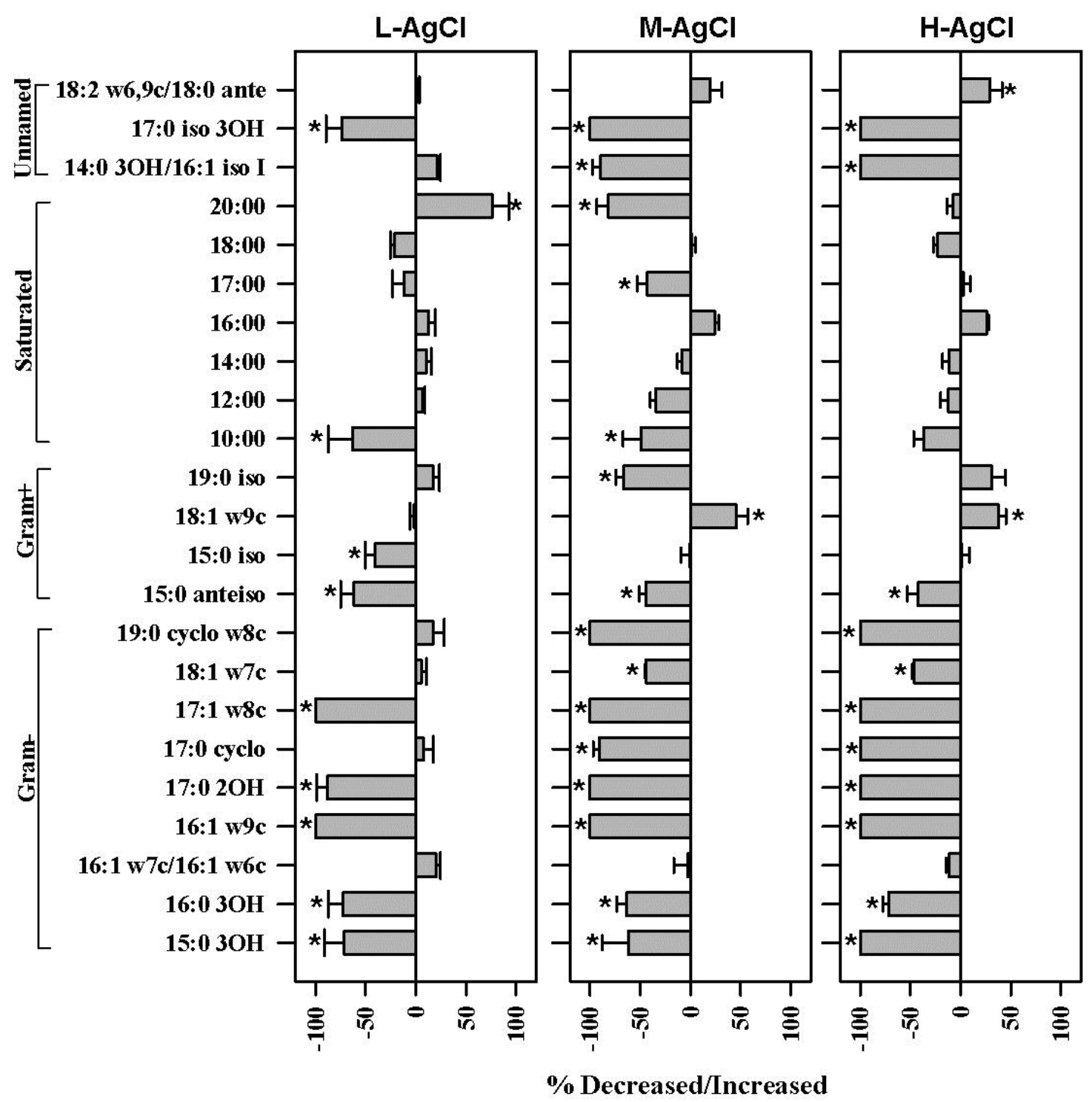

Figure 2: The percentage, either decreased or increased, in MET-1 fatty acid profiles of AgCl treatments at $25(\mathrm{~L}-\mathrm{AgCl}), 100$ (M-AgCl) and $200(\mathrm{H}-\mathrm{AgCl}) \mathrm{mg} / \mathrm{L}$ concentrations, respectively, compared to controls (no AgCl colloids). Bars represent the means of three independent fatty acid assessments and standard errors. Fatty acids are grouped according to their most-frequently associated categories. Unknown lipid indicators are indicated as 'Unnamed'. The symbol '*' represents significant differences $(p<0.05)$ compared to controls.

appearance of individuals with argyria [31]. However, the impact on the gut microbiome has not been previously explored. Here we show that colloidal Ag in the range of concentrations achieved after self-administration or inadvertent exposure can shift the microbial community significantly. Even at $25 \mathrm{mg} / \mathrm{L}$ colloidal $\mathrm{AgCl}$, there was a $20 \%$ decline in respiration, fatty acid signatures of certain bacterial groups were reduced by $15-100 \%$, and there was a distinct shift in the phylogenetic diversity and evenness as assessed by both the PCR-DGGE and pyrosequence analysis. The impact to the bacterial community was concentration-dependent; and at the two highest dosages used, the consortium no longer resembled the initial inoculum. It is important to recall that MET-1 was designed as a therapeutic consortium in order to treat patients suffering from pathogenic bacteria and other conditions $[25,37]$, and thus the species used in its formulation could be defined as 'probiotic'. Therefore, the loss of any of these species may be significant. For example, Dorea longicatena although only representing $0.2 \%$ of the original consortium, was completely eliminated in all of the Ag colloid treatment groups. Importantly, this species is thought to be essential for healthy microbiota homeostasis [38].

Other bacteria are central for nutrient utilization. The commensal Bacteroides ovatus, for example, is valued for its enzymatic contribution to carbohydrate metabolism [39]. In the presence of $25 \mathrm{mg} / \mathrm{L}$ colloidal $\mathrm{AgCl}$, its abundance dropped from 35 - 6\%. Under these conditions then, it is perhaps not surprising that Escherichia and Raoultella, two genera from the Enterobacteriaceae, increased in abundance since they would likely be able to utilize available carbohydrate substrates [40]. At still higher concentrations of colloidal $\mathrm{AgCl}$, these genera decreased, as it is known that $\mathrm{AgCl}$ is highly toxic to these Gram negatives [41]. In addition, two other butyrate-producing anaerobes, Faecalibacterium prausnitzii and Roseburia spp., which are considered to be essential due to their anti-inflammatory and immune-modulatory properties, were 
Citation: Das P, Petrof EO, Walker VK (2015) Perturbation of a Human Gut Ecosystem by Silver Chloride Colloids. J Environ Anal Toxicol 5: 294. doi:10.4172/2161-0525.1000294

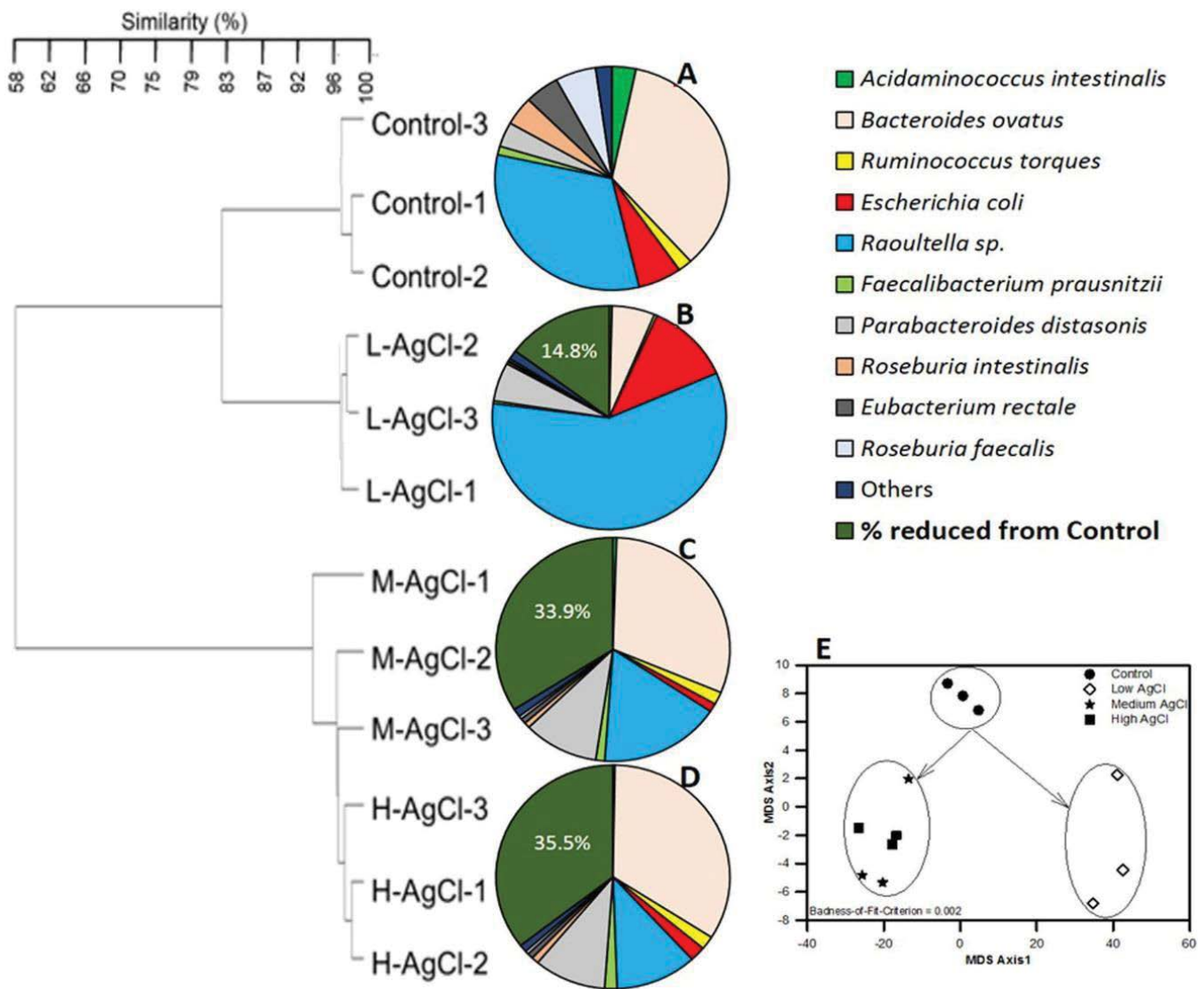

Figure 3: The impact of $\mathrm{AgCl}$ colloids on MET-1 DNA analyses. Left pane/ shows the UPGMA clustering analysis (dendrogram) using the observed PCR-DGGE band patterns generated after exposure to $\mathrm{AgCl}$ and control (no Ag), where the $\mathrm{L}-, \mathrm{M}$ - or $\mathrm{H}$ - prefix before $\mathrm{AgCl}$ represents 25,100 and $200 \mathrm{mg} / \mathrm{L}$ concentrations, respectively. Numbers at the end of the descriptors $(1,2,3)$ indicate each of the replicate samples. Mid panel shows the human gut bacterial phylogenetic composition (species level) normalized to the total fatty acids after $48 \mathrm{~h}$ exposure to A) 0 (Control), B) 25 (L-AgCl), C) $100(\mathrm{M}-\mathrm{AgCl})$, and D) $200(\mathrm{H}-\mathrm{AgCl}) \mathrm{mg} / \mathrm{L} \mathrm{AgCl}$ colloids, respectively. Means of the triplicate samples in each treatment (with $>1 \%$ relative abundance) were used for sequence identity, whereas less abundant species are shown as 'Others'. The quantity of the total phylogenetic composition reduced in different $\mathrm{AgCl}$ treatment groups from control (with no $\mathrm{Ag}$ ) is shown (\%) in the mid panels $\mathrm{B}, \mathrm{C}$ and $\mathrm{D}$. Right Panel (Panel E) shows multidimensional scaling (MDS) plots of human gut bacterial community composition after $48 \mathrm{~h}$ exposure to 0 (Control), 25 (Low), 100 (Medium) and 200 (High) mg/L AgCl, respectively. Arrows indicate the distance of the $\mathrm{AgCl}$ - treatment groups from the control with no Ag.

also significantly $(p<0.01)$ reduced by $68-92 \%$ in the colloidal $\mathrm{AgCl}$ treatment groups. Taken together, these observations suggest that there could be a considerable impact on the metabolic activities in our gut ecosystem after colloidal Ag ingestion.

Colloidal Ag toxicity to bacteria is reported to be a function of particle size and the release of $\mathrm{Ag}^{+}$in the suspension [42,43]. Similar to Choi et al. [42], the particle size used here $(\sim 2 \mu \mathrm{m})$ was the same for every treatment group and thus the observed dose-dependent toxicity is assumed to be related to the dissociation of colloidal $\mathrm{AgCl}$ into $\mathrm{Ag}^{+}$and $\mathrm{Cl}-\mathrm{Ag}+$ is known to interact with sulfhydryl groups, replacing $\mathrm{H}$ atoms, resulting in $\mathrm{S}-\mathrm{Ag}$ bonds in the bacterial membrane, inhibiting respiration and collapsing the proton motive force, and ultimately resulting in cell death $[44,45]$. The two highest $\mathrm{AgCl}$ concentrations (100 and $200 \mathrm{mg} / \mathrm{L}$ ) would have exerted high toxicity due to the dissociated $\mathrm{Ag}^{+}$. It is also possible that the bacteria were more sensitive to $\mathrm{Ag}^{+}$-mediated toxicity in the presence of the halide $[46,47]$. The effects of $\mathrm{Ag}^{+}$can be reduced in the presence of moderate concentrations of $\mathrm{Cl}-$, however, at higher levels of $\mathrm{Cl}-$, bioavailable $\mathrm{Ag}^{+}$ increased due to the formation of dichloro-silver ion $\left(\mathrm{AgCl}_{2}^{-}\right)$. Since we used a two-fold concentration of $\mathrm{Cl}$ - (as $\mathrm{NaCl}$ ) to make colloidal $\mathrm{AgCl}$ in these experiments, this is the probable source of $\mathrm{Ag}^{+}$toxicity at the high concentrations tested.

Regardless of the mechanism, we have shown that in this model system, significant changes in human gut microbial diversity and evenness can result from colloidal $\mathrm{AgCl}$ exposure. Thus a possible negative impact on digestive health is a cautionary note for those that are exposed, either by self-inflicted or accidental oral ingestion.

\section{Conclusion}

The bactericidal and fungicidal properties of $\mathrm{Ag}$ or aliquot $\mathrm{Ag}$ salt colloids make them popular in a number of commercial and medical applications and have also encouraged sales of colloidal Ag as a dietary supplement. Based on our investigations of a defined anaerobic gut microbial ecosystem (MET-1), however, Ag colloid treatments (25 $200 \mathrm{mg} / \mathrm{L}$ ) had an overall deleterious impact on bacterial abundance and metabolic activity. This was evidenced by significant changes in 
bacterial respiration, fatty acid profiles and community structure. Some 'probiotic' bacteria appeared to be eliminated by the Ag treatment even at the lowest concentrations tested, suggesting to us that colloidal $\mathrm{Ag}$ ingestion could have a potential negative impact on our overall digestive health.

\section{Competing Interests}

All authors declare that they have no competing interests.

\section{Acknowledgements}

We thank Dr. J.A.K. McDonald (Department of Medicine, Kingston General Hospital, Queen's University, Kingston, ON) for helping to set up the experiments in Ruskinn anaerobic chamber. The authors also thank Dr. G. Cairns (Analytical Services Lab, Queen's University), Drs. K. Jarrell (Queen's University), E. AllenVercoe (University of Guelph) and Ms. M. Hay (Keystone Labs Inc.) for assistance with the gas chromatography, encouragement, and fatty acid analyses, respectively. This research was funded by an NSERC Discovery grant to VKW.

\section{References}

1. Lansdown $A B$ (2002) Silver. 2: Toxicity in mammals and how its products aid wound repair. J Wound Care 11: 173-177.

2. Lansdown AB (1995) Physiological and toxicological changes in the skin resulting from the action and interaction of metal ions. Crit Rev Toxicol 25: 397 462

3. Alexander JW (2009) History of the medical use of silver. Surg Infect (Larchmt) 10: $289-292$

4. Holler JS, Nordberg GF, Fowler BA (2007) Silver. In: Nordberg, GF, Fowler BA Nordberg M, Friberg, LT (Eds) Handbook on the Toxicology of Metals, 3rd Ed. Academic Press, Elsevier, UK, 809-814.

5. Gulbranson SH, Hud JA, Hansen RC (2000) Argyria following the use of dietary supplements containing colloidal silver protein. Cutis 66: 373-374.

6. Klasen $\mathrm{HJ}(2000)$ Historical review of the use of silver in the treatment of burns. I. Early uses. Burns 26: 117-130.

7. White RJ (1999) A historical review of silver in would management. Br J Nurs S3-S8.

8. Hambidge A (2001) Reviewing efficacy of alternative water treatment techniques. Health Estate 55: 23-25.

9. Davies RL, Etris SF (1997) The development and functions of silver in water purification and disease control. Catalysis Today 36: 107-114.

10. Clemente GF, Cignarossi L, Santaroni GP (1977) Trace-element intake and excretion in Italian population. J Radioanal Chem 37: 549-558.

11. Gibson RS, Scythes CA (1984) Chromium, selenium, and other trace element intakes of a selected sample of Canadian premenopausal women. Biol Trace Elem Res 6: 105-116.

12. Hamilton El, Minski MJ (1973) Abundance of the chemical elements in man's diet and possible relations with environmental factors. Sci Total Environ 1: $375-$ 394.

13. Wan AT, Conyers RA, Coombs CJ, Masterton JP (1991) Determination of silver in blood, urine, and tissues of volunteers and burn patients. Clin Chem 37: 1683-1687.

14. Lansdown AB, Williams A, Chandler S, Benfield S (2005) Silver absorption and antibacterial efficacy of silver dressings. J Wound Care 14: 155-160.

15. Fung MC, Bowen DL (1996) Silver products for medical indications: risk-benefit assessment. J Toxicol Clin Toxicol 34: 119-126.

16. Chang AL, Khosravi V, Egbert B (2006) A case of argyria after colloidal silver ingestion. J Cutan Pathol 33: 809-811.

17. McIntyre E, Wilcox J, McGill J, Lewindon PJ (2001) Silver toxicity in an infant of strict vegan parents. J Pediatr Gastroenterol Nutr 33: 501-502.

18. OLCOTT CT (1950) Experimental argyrosis; hypertrophy of the left ventricle of the heart in rats ingesting silver salts. AMA Arch Pathol 49: 138-149.

19. Shavlovski MM, Chebotar NA, Konopistseva LA, Zakharova ET, Kachourin AM, et al. (1995) Embryotoxicity of silver ions is diminished by ceruloplasmin- -further evidence for its role in the transport of copper. Biometals 8: 122-128.

20. Mirsattari SM, Hammond RR, Sharpe MD, Leung FY, Young GB (2004) Myoclonic status epilepticus following repeated oral ingestion of colloidal silver Neurology 62: 1408-1410.

21. Payne AN, Zihler A, Chassard C, Lacroix C (2012) Advances and perspectives in in vitro human gut fermentation modeling. Trends Biotechnol 30: 17-25.

22. RajiliÄ-StojanoviÄ M, Smidt $H$, de Vos WM (2007) Diversity of the human gastrointestinal tract microbiota revisited. Environ Microbiol 9: 2125-2136.

23. Bäckhed F, Fraser CM, Ringel Y, Sanders ME, Sartor RB, et al. (2012) Defining a healthy human gut microbiome: current concepts, future directions, and clinical applications. Cell Host Microbe 12: 611-622.

24. Thompson-Chagoyán OC, Maldonado J, Gil A (2005) Aetiology of inflammatory bowel disease (IBD): role of intestinal microbiota and gut-associated lymphoid tissue immune response. Clin Nutr 24: 339-352.

25. Petrof EO, Gloor GB, Vanner SJ, Weese SJ, Carter D, et al (2013) Stoo substitute transplant therapy for the eradication of Clostridium difficile infection: 'RePOOPulating' the gut. Microbiome 1: 3.

26. Das P, McDonald JAK, Petrof EO, Allen-Vercoe E, Walker VK (2014) NanosilverMediated Change in Human Intestinal Microbiota. J Nanomed Nanotechnol 5 : 235

27. Baker CD, Federico MJ, Accurso FJ (2007) Case report: skin discoloration following administration of colloidal silver in cystic fibrosis. Curr Opin Pediatr 19: 733-735

28. Brandt D, Park B, Hoang M, Jacobe HT (2005) Argyria secondary to ingestion of homemade silver solution. J Am Acad Dermatol 53: S105-107.

29. Das P, Xenopoulos MA, Williams CJ, Hoque ME, Metcalfe CD (2012) Effects of silver nanoparticles on bacterial activity in natural waters. Environ Toxicol Chem 31: 122-130.

30. McDonald JA, Schroeter K, Fuentes S, Heikamp-dejong I, Khursigara CM, et al. (2013) Evaluation of microbial community reproducibility, stability and composition in a human distal gut chemostat model. J Microbiol Methods 95:167-174.

31. Lansdown AB (2010) A pharmacological and toxicological profile of silver as an antimicrobial agent in medical devices. Adv Pharmacol Sci 2010: 910686.

32. Wadhera A, Fung M (2005) Systemic argyria associated with ingestion of colloidal silver. Dermatol Online J 11: 12.

33. Sasser M (1990) Identification of bacteria by gas chromatography of cellular fatty acids, Tech note \# 101, MIDI, Newark, DE.

34. Bartelt-Ryser J, Joshi J, Schmid B, Brandi H, Balser T (2005) Soil feedbacks of plant diversity on soil microbial communities and subsequent plant growth Perspectives in Plant Ecology, Evol \& Systematics 7: 27-49.

35. Muyzer G, de Waal DC, Uitterlinden AG (1993) Profiling of complex microbial populations by denaturing gradient gel electrophoresis analysis of polymerase chain reaction-amplified genes coding for $16 \mathrm{~S}$ rRNA. Appl Environ Microbiol 59: $695-700$

36. Handl S, Dowd SE, Garcia-Mazcorro JF, Steiner JM, Suchodolski JS (2011) Massive parallel 16S rRNA gene pyrosequencing reveals highly diverse fecal bacterial and fungal communities in healthy dogs and cats. FEMS Microbio Ecol 76: 301-310.

37. Petrof EO, Claud EC, Gloor GB, Allen-Vercoe E (2013) Microbial ecosystems therapeutics: a new paradigm in medicine? Benef Microbes 4: 53-65.

38. Tap J, Mondot S, Levenez F, Pelletier E, Caron C, et al. (2009) Towards the human intestinal microbiota phylogenetic core. Environ Microbiol 11: 2574 2584.

39. Wexler HM (2007) Bacteroides: the good, the bad, and the nitty-gritty. Clin Microbiol Rev 20: 593-621.

40. Kinross JM, Darzi AW, Nicholson JK (2011) Gut microbiome-host interactions in health and disease. Genome Med 3: 14

41. Adams AP, Santschi EM, Mellencamp MA (1999) Antibacterial properties of a silver chloride-coated nylon wound dressing. Vet Surg 28: 219-225.

42. Choi O, Deng KK, Kim NJ, Ross L Jr, Surampalli RY, et al. (2008) The inhibitory effects of silver nanoparticles, silver ions, and silver chloride colloids on microbial growth. Water Res 42: 3066-3074. 
Citation: Das P, Petrof EO, Walker VK (2015) Perturbation of a Human Gut Ecosystem by Silver Chloride Colloids. J Environ Anal Toxicol 5: 294. doi:10.4172/2161-0525.1000294

Page 7 of 7

43. Ratte HT (1999) Bioaccumulation and toxicity of silver compounds: a review. Environ Toxicol Chem 18: 89-108.

44. Dibrov P, Dzioba J, Gosink KK, Häse CC (2002) Chemiosmotic mechanism of antimicrobial activity of $\mathrm{Ag}(+)$ in Vibrio cholerae. Antimicrob Agents Chemother 46: $2668-2670$.

45. Russell AD, Hugo WB (1994) Antimicrobial activity and action of silver. Prog Med Chem 31: 351-370.
46. Gupta A, Maynes M, Silver S (1998) Effects of halides on plasmid-mediated silver resistance in Escherichia coli. Appl Environ Microbiol 64: 5042-5045

47. Li XZ, Nikaido H, Williams KE (1997) Silver-resistant mutants of Escherichia coli display active efflux of $\mathrm{Ag}+$ and are deficient in porins. J Bacteriol 179 : 6127-6132. 